\title{
NON-BIOMIMETIC ROUTE TO DEOXYADENOSINE ADDUCTS OF CARCINOGENIC POLYCYCLIC AROMATIC HYDROCARBONS
}

\author{
Seong Jin Kim, a Constance M. Harris, ${ }^{\text {a Kee-Yong Jung, }}{ }^{b}$ \\ Masato Koreeda, ${ }^{b}$ and Thomas M. Harrisa,"
}

\author{
a Department of Chemistry and Center in Molecular Toxicology, Vanderbilt University, \\ Nashville, TN 37235; bepartment of Chemistry, University of Michigan, Ann Arbor, MI 48109
}

Summary: Aminotriols are prepared by direct aminolysis of the diol epoxides of polycyclic aromatic hydrocarbons, providing a substantial improvement over literature methods. The condensation of aminotriols with 6-halopurine deoxyribonucleosides provides a regio- and stereospecific synthesis of deoxyadenosine $\mathrm{N}^{6}$ adducts.

Carcinogenic polycyclic aromatic hydrocarbons (PAHs) are widespread in the environment. They require metabolic activation to become genotoxic. Much evidence points to the ultimate carcinogenic species being dihydrodiol epoxide melabolites (1) which react at a variety of sites in DNA. ${ }^{1}$ Low adduction yields, both in mono- and oligonucleotides, and imperfect regio- and stereospecificity present serious roadblocks for systematic structural and biochemical studies. With benzo[a]pyrene and many other PAHs, only minute quantities of adenine $\mathrm{N}^{6}$ adducts (2) are formed $s^{2}$ but these adducts may play a disproportionate role in oncogenesis. ${ }^{3}$ Several groups have reported syntheses of adenine nucleosides adducted at $\mathrm{N}^{6}$ by a reversal of the electrophilenucleophile relationship using amine derivatives of the PAH in condensations with 6halopurine nucleosides (e.g., 3) but these studies have been limited to less functionalized and sterically less demanding amines. ${ }^{4}$ Herein we report an efficient route to PAH aminotriols (4) plus their use in a non-biomimetic but regio- and stereospecific route to deoxyadenosine-PAH adducts. Naphthalene and benzo[a]pyrene are used to demonstrate the methodology. 
<smiles>CC1=CC2CC(C1O)C2O</smiles><smiles>Nc1ncnc2c1ncn2-c1ccccc1</smiles><smiles>CC1CC(O)C(O)C(O)C1Nc1ncnc2c1ncn2O</smiles>

2<smiles>NC1CCCCC1CO</smiles>

Non-blomimetic<smiles>[Y]c1ncnc2c1ncn2[10BH2]</smiles>

Interest in non-biomimetic routes to adducted nucleosides led Smith et al. ${ }^{5}$ to develop a two-step stereospecific synthesis of ( \pm )-1-amino-1,2,3,4-tetrahydronaphthalene-2,3,4-triol (4a) from diol epoxide $1 \mathrm{a}$ in $20 \%$ yield via an intermediary isonitrile. We have now found the transformation can be achieved quantitatively and stereospecifically in a single step by treatment of the diol epoxide with anhydrous ammonia for $21 \mathrm{hr}$ at $70^{\circ} \mathrm{C}$ in a Parr pressure reactor (20 atm). Condensation of $\left( \pm\right.$ )-aminotriol 4a with chloronucleoside $3 \mathrm{a}\left[1: 1 \mathrm{4a:3a}, 55^{\circ} \mathrm{C}, 7\right.$ days, Et ${ }_{3} \mathrm{~N}$ (5 equiv), $\mathrm{CH}_{3} \mathrm{CONMe}_{2}$ g gave the diastereomeric deoxyadenosine $\mathrm{N}^{6}$ adducts (2a) in $-60 \%$ yield. The structure of $2 \mathrm{a}$ was established spectroscopically. ${ }^{6}$<smiles>OC1c2ccccc2C2OC2[C@H]1O</smiles>

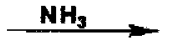

$1 \mathbf{a}$<smiles>NC1c2ccccc2C(O)[C@H](O)[C@H]1O</smiles>

48
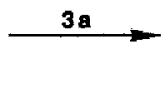<smiles>CC(C)[C@H](C)N</smiles>

The methodology has been extended to benzo[a]pyrene which is the most extensively studied of the carcinogenic PAHs. Two research groups have recently prepared racemic aminotriol $4 \mathrm{~b}$ from ( $(\mathbf{)}$ )-anti diol epoxide (1b) by two-step procedures involving ring opening by azide followed by reduction. 7,8 We find the direct aminolysis procedure $\left(70^{\circ} \mathrm{C}, 24 \mathrm{~h}\right)$ with $(+)-1 \mathrm{~b}$ gives aminotriol $\mathbf{4 b}$ stereospecifically in essentially quantitative yield. The structure of chiral $\mathbf{4 b}$ was established spectroscopically; the NMR spectrum in DMSO was identical to that reported by Jhingan and Meehan. 8 Confirmation was obtained by physical comparison of the N-acetyl 
derivative ${ }^{10}$ using an authentic sample (prepared from the racemic $4 \mathbf{b}$-tris(benzoate ester) ${ }^{7}$ kindly provided by Prof. R. E. Lehr (Univ. of Oklahoma).

The condensation of optically active $4 b$, derived from $(+)-1 b$, with chloronucleoside $3 a(1: 2$ of $4 \mathrm{~b}: 3 a$ ) under the same conditions as for $4 a$ gave the deoxyadenosine $\mathrm{N}^{6}$ adduct $2 \mathrm{~b}$ in $12 \%$ yield. The adduction reaction is slowed by steric hindrance relative to that observed with the naphthalene aminotriol. Efficient conversion (85\%) to $\mathbf{2 b}$ was observed with the more reactive fluoro nucleoside $3 b^{11}$ (2:1 of ( $( \pm)-4 b: 3 b, 55^{\circ} \mathrm{C}, \mathrm{Et}_{3} \mathrm{~N}, \mathrm{CH}_{3} \mathrm{CONMe}, 48 \mathrm{~h}$ ). The two diastereomers were separated by $\mathrm{C}-18$ reverse-phase $\mathrm{HPLC}$ (13.8 and $14.4 \mathrm{~min}$ in a $\mathrm{MeOH} / \mathrm{H}_{2} \mathrm{O}$ gradient); the faster eluting one corresponded to the previously prepared adduct derived from $(+)-1 \mathbf{b}$. The NMR spectra of the two diastereomers were virtually indistinguishable except for minor chemical shift differences $(0.01 \sim 0.02 \mathrm{ppm})$ for some of the deoxyribose protons. 12 Adducts $\mathbf{1 b}$ at the $\mathrm{N}^{6}$ position of deoxyadenosine have previously been prepared by Jeffrey et al. (using poly $\mathrm{dA}$ ) and Cheng et al. (using calf thymus DNA) by reaction with the diol epoxide followed by degradation of the DNA and HPLC isolation. ${ }^{2}$ The CD spectrum of the more mobile diastereomer was identical to that reported by Cheng et al. for the trans adduct of $(+)-1 b$, while the slower one corresponded to the trans adduct of (-)-1b.

A comparison of the ${ }^{1} \mathrm{H}$ NMR spectra6,12 of $2 a$ and $2 b$ provides insight into the effect of steric constraints imposed by the tetrahydrobenzo[a]pyrenyl moiety as compared with the tetrahydronaphthalene. With naphthalene adduct $2 \mathbf{a}$, the vicinal coupling constant, $J_{3,4}$, of the $\mathrm{CH}$ to which the adenine is attached is $6.9 \mathrm{~Hz}$, whereas the corresponding coupling constant, $/ 9,10$, in benzo[a]pyrene adduct $\mathbf{2 b}$ is only $3.3 \mathrm{~Hz}$. The difference reflects the fact that the adenine moiety is forced out of the plane of the aromatic ring much more severely in the case of the bay region benzo[a]pyrene derivative. This difference in nucleoside conformation can be expected to occur in PAH-adducted DNA as well and may contribute to the greater carcinogenicity of bay region PAH diol epoxides.

The ability of $\mathbf{3 b}$ to react with hindered amines is noteworthy and appears to be quite general; we have observed condensation even with the highly congested aminotriol derived from the bay region diol epoxide of benzo[c]phenanthrene. The condensation reaction should have wide applicability to the synthesis of deoxyadenosine adducts.

This study was supported by NIH grants ES00267, ES05509, and CA25185.

\section{References}

1) Sims, P.; Grover, P. L.; Swaisland, A.; Pal, K.; Hewer, A. Nature, 1974, 252, 326. Reviewed by: Harvey, R. G.; Geacintov, N. E. Acc. Chem. Res., 1988, 21, 66.

2) (a) Cheng, S. C.; Hilton, B. D.; Roman, J. M.; Dipple, A. Chem. Res. Toxicol., 1989, 2, 334. (b) Jeffrey, A. M.; Grzeskowiak, K; Weinstein, I. B.; Nakanishi, K., Roller, P., Harvey, R. G. Science, 1979, 206, 1309.

3) Vousden, K. H.; Bos, J. L.; Marshall, C. J.; Phillips, D. H. Proc. Natl. Acad. Sci. USA, 1986, 83, 1222; Dipple, A.; Pigott, M.; Moschel, R. C.; Costantino, N. Cancer Res., 1983, 43, 4132. 
4) (a) Lee, H.; Hinz, M.; Stezowski, J. J.; Harvey, R. G. Tetrahedron Lett., 1990, 31, 6773. (b) Lakshman, M.; Lehr, R. E. Tetrahedron Lett., 1990, 31, 1547. (c) Bartczak, A. W.; Sangaiah, R.; Kelman, D. J.; Toney, G. E.; Deterding, L. J.; Charles, J.; Marbury, G. D.; Gold, A. Tetrahedron Lett., 1989, 30, 3251.

5) Smith, C. A.; Harper, A. E.; Coombs, M. M. J. Chem. Soc, Perkins Trans. I, 1988, 2745.

6) Nucleoside 2a. ${ }^{1} \mathrm{H}$ NMR (d4-MeOH) naphthalene fragment: $\mathrm{H} 14.75 \mathrm{~d}, \mathrm{H} 24.10 \mathrm{dd}, \mathrm{H3} 4.28$ dd, H4 5.71 broad, H5 7.28 dd, H6 7.24 ddd, H7 7.31 ddd, H8 7.50 dd; $J_{1,2} 5.6, J_{2,3} 2.3, J_{3,4} 6.9, J_{5,6}$ $7.9, I_{5,7} 1.9, J_{6,7} 6.7, I_{6,8} 1.4, I 7,87.6 \mathrm{~Hz}$, unresolved long-range couplings $\mathrm{H} 1 \leftrightarrow \mathrm{H} 8$ and $\mathrm{H} 4 \leftrightarrow \mathrm{H} 5$; adenine fragment: $\mathrm{H} 28.27$ broad s, $\mathrm{H} 88.24$ sharp s; deoxyribose fragment: $\mathrm{H}^{\prime}{ }^{\prime} 6.44$ dd, H2' ( $\beta$ ) 2.82 ddd, H2" ( $\alpha) 2.41$ ddd, H3' 4.58 td, H4' 4.08 q, H5' 3.85 dd, H5" 3.74 dd; J1',2'

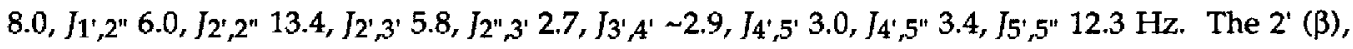
$5^{\prime}$, and $5^{\prime \prime}$ protons of the two diastereomers had slightly different chemical shifts, $\Delta \delta \sim 0.003$ ppm. MS (electrospray) of 2a pentaacetate: Calcd for $\mathrm{C}_{30} \mathrm{H}_{33} \mathrm{~N}_{5} \mathrm{O}_{11}+\mathrm{H}^{+}: 640$ : Observed: 640 .

7) Lakshman, M.; Nadkarni, D. V.; Lehr, R. E. J. Org. Chem., 1990, 55, 4892.

8) Jhingan, A. K.; Meehan, T. J. Chem Research (S), 1991, 122; J. Chem. Research (M), 1991, 1071.

9) Aminotriol 4b derived from (+)-1b. 1H NMR ( $d_{6}$-acetone $+\mathrm{H}^{+}$): $\mathrm{H} 68.57 \mathrm{~s}, \mathrm{H} 75.25 \mathrm{~d}, \mathrm{H} 84.24$ dd, H9 4.06 dd, H10 5.67 d; $J_{7,8} 8.6, J_{8,9} 2.0, J_{9,10} 3.2$ Hz; (DMSO-d 6 ): H7 4.89 d, H8 4.15 dd, H9 4.09 dd, H10 4.77 d; $J 7,8$ 8.6, J8,9 2.1, J9,10 $3.2 \mathrm{~Hz}$. UV (MeOH): 342 (33,000), 326 (22,000), 312 $(9,300), 278(34,000), 266(20,600), 244(60,000), 237 \mathrm{~nm}(36,800)$. The CD spectrum contained negative Cotton effects at 346 and $328 \mathrm{~nm}$ and a positive Cotton effect at $282 \mathrm{~nm}$. MS (FAB+): Calcd for $\mathrm{C}_{20} \mathrm{H}_{17} \mathrm{NO}_{3}+\mathrm{H}^{+}: 320.1286$. Observed: 320.1298 .

10) N-Acetyl derivative of $4 \mathrm{~b}$. MS (FAB+): Calcd for $\mathrm{C}_{22} \mathrm{H}_{19} \mathrm{NO}_{4}+\mathrm{H}^{+}: 362.1392$. Observed: 362.1396.

11) Robins, M. J.; Basom, G. L. Can. J. Chem., 1973, 51, 3161.

12) Nucleoside $2 b$ derived from (+)-1b. ${ }^{1} \mathrm{H}$ NMR BP fragment: $\mathrm{H1} 8.16 \mathrm{dd}, \mathrm{H} 27.98 \mathrm{t}, \mathrm{H3} 8.19 \mathrm{dd}$, H4 8.08 d, H5 8.12 d, H6 8.57 d, H7 5.24 dd, H8 4.25 dd, H9 4.56 dd, H10 6.49 broad, I111 8.09 broad d, 8.03 d; $J_{1,2} 7.7, J_{2,3} 7.7, J_{1,3} 1.2, J_{4,5} 9.1, J_{6,7} 1.0, J_{7,8} 9.0 J_{8,9} 2.2, J_{9.10} 3.3, J_{11,12} 9.4 \mathrm{~Hz}$; adenine fragment: $\mathrm{H} 28.53$ broad s, $\mathrm{H} 88.18$ broad s; deoxyribose fragment: $\mathrm{H} 1$ ' 6.44 broad $\sim \mathrm{t}$, H2' ( $\beta$ ) 2.85 ddd, H2" ( $\alpha$ ) 2.42 ddd, H3' 4.59 ddd, H4' $4.08 \sim q, H 5^{\prime} 3.85$ dd, H5" 3.74 dd; I1',2' $8.2, J_{1}^{\prime}, 2^{\prime \prime} 6.0, J_{2}^{\prime}, 2^{\prime \prime} 13.6, J_{2}^{\prime}, 3^{\prime} 5.7, J_{2}^{\prime \prime}, 3^{\prime} 2.7, J_{3^{\prime}, 4^{\prime}} \sim 2.6, J_{4^{\prime}}{ }^{\prime} 5^{\prime} 3.0, J_{4^{\prime}}, 5^{\prime \prime} 3.4, J_{5^{\prime}, 5^{\prime \prime}} 12.5 \mathrm{~Hz}$. Nucleoside 2b derived from (-)-1b was essentially identical except for H2' 2.83, H3' 4.58, H5' 3.87, $\mathrm{H} 5 "$ 3.76. MS (FAB+) of $2 \mathrm{~b}$ pentaacetate: Calcd for $\mathrm{C}_{40} \mathrm{H}_{37} \mathrm{~N}_{5} \mathrm{O}_{11}+\mathrm{H}^{+}: 764$. Observed: 764 .

(Received in USA 10 May 1991) 